JOSING: Journal of Nursing and Health

Volume 2, Nomor 1, Desember 2021

e-ISSN: 2745-7877

p-ISSN: 2746-0851

DOI: https://doi.org/10.31539/josing.v2i1.3023

\title{
EDUCATION ON THE KNOWLEDGE OF YOUTH ABOUT YOUTH CARE HEALTH SERVICES (PKPR)
}

\author{
Andry Sartika ${ }^{1}$, Oktarianita $^{2}$, Padila $^{3}$, Juli Andri ${ }^{4}$, \\ Muhammad Bagus Andrianto ${ }^{5}$ \\ University of Muhammadiyah Bengkulu $u^{1,2,3,4,5}$ \\ padila@umb.ac.id ${ }^{3}$
}

\begin{abstract}
This study aims to determine the effect of counseling on adolescent knowledge about Youth Care Health Services (PKPR) at the Bintang Terampil Orphanage, Bengkulu City. This type of research is quantitative research conducted at the Bintang Terampil Orphanage, Bengkulu City. The population observed was all 30 adolescents in the Bintang Skilled Orphanage, Bengkulu City, with a total sampling technique of selecting samples. Data collection was carried out by distributing questionnaires containing questions to adolescents about PKPR twice to determine their pretest and posttest knowledge about PKPR. Information was obtained in the univariate and bivariate test analysis. The results showed that the average knowledge score before counseling was 8.57, and after counseling was 12.13. Adolescents' knowledge about PKPR before and after counseling was a mean value of 3.567, a standard deviation of 2.208, with a pvalue of 0.005. In conclusion, there are differences in adolescent knowledge about PKPR before and after counseling.
\end{abstract}

Keywords: Adolescent Knowledge, Counseling, PKPR

\section{INTRODUCTION}

The high number of injuries in school-age children and adolescents, as shown by Riskesdas 2018 states that the proportion of adolescents who smoke reaches 5.3\%. As many as $4 \%$ of adolescents have consumed alcohol, $58.8 \%$ of teenage pregnancies, and the proportion of lack of physical activity in adolescents. adolescents 10-14 years $64.4 \%, 15-19$ years $49.6 \%$. In addition, nutritional problems also need special attention from the government and the community, as shown. For children aged 5-12 years, $6.7 \%$ are concise, $16.9 \%$ are short, $2.4 \%$ are skinny, $6.8 \%$ are thin, and $9.2 \%$ of adolescents are obese (Riskesdas, 2018).

Health problems in adolescents certainly require comprehensive and integrated handling by involving all relevant elements and cross-sectors. The health policy related to health services for adolescents, as stated in the Minister of Health Regulation Number 25 of 2014, aims to make adolescents have the ability to behave in a clean and healthy life, healthy life skills, and good social skills so that adolescents can grow and develop harmoniously and optimally into quality adolescents (Kemenkes RI, 2018; Febriawati et al., 2018).

Adolescent Care Health Service (PKPR) is one of the health services intended for adolescents aged 10-19 years. PKPR aims to improve the knowledge and skills of adolescents about reproductive health and healthy living behavior and provide quality health services for adolescents (Kemenkes RI, 2019). The principle of the PKPR 
program is that teenagers can access health services, accept teenagers, have fun and maintain confidentiality about teenagers (A'yun \& Qomaruddin, 2019).

Rahmah et al. (2020) stated that good knowledge in adolescents significantly affects adolescents in utilizing PKPR. Information is one of the things that can affect a person's level of knowledge. The existence of the provision of new information raises a high interest in something. By getting information, it can help someone to gain new knowledge. Interest makes a person try and pursue something and, in the end, gain more profound knowledge (Wijaya \& Widjokongko, 2019). Young people need to know that PKPR services are not just counseling in schools by PKPR Puskesmas officers, but PKPR services can also be carried out directly at the Puskesmas (Dewi et al., 2020).

Based on the results of an initial survey of children's knowledge about PKPR, it is known that children have not received complete information about health services, including health services for adolescents such as the Youth Care Health Service (PKPR). This research needs to be done as essential information to know the effect of counseling on adolescent knowledge about PKPR. Later, it can help increase adolescent knowledge and use PKPR services that are right on target.

\section{RESEARCH METHOD}

This research design is quantitative. This research was carried out at the Bintang Terampil Orphanage, Bengkulu City, in February-March 2021. The population in the study was 30 teenagers from the Bintang Terampil Orphanage. Research sample with Total Sampling. They were collecting data by distributing questionnaires containing questions to adolescents about PKPR.

Measurements were carried out two times to determine the knowledge of pretest and posttest of adolescents about PKPR. The questions given were 15 questions about PKPR with four answer choices; if correct, then given a one and a lousy score of 0 . After the calculation, entered the data tabulation, followed by testing the normality of the data, it was found that the data was not normally distributed. The Wilcoxon and Mann Whitney test was carried out to get the p-value.

\section{RESULTS \\ Univariate Analysis}

Table. 1

Characteristics of respondents

\begin{tabular}{ccc}
\hline Gender & Frequency & $\%$ \\
\hline Man & 21 & 70 \\
Woman & 9 & $30 \%$ \\
\hline Respondent's age & Frequency & $\%$ \\
\hline $10-14$ Year & 16 & $53 \%$ \\
$15-19$ Year & 14 & $47 \%$ \\
\hline
\end{tabular}

Based on table 1 the characteristics of the respondents above, there are as many as $21(70 \%)$ teenage boys and $9(30 \%)$ teenage girls at the Bintang Terampil Orphanage. Adolescents aged 10-14 years as many as 16 people (53\%) and teenagers aged 15-19 years as many as 14 people (47\%). 
Table. 2

Knowledge Before and After Giving Counseling

\begin{tabular}{ccccc}
\hline Youth Knowledge & Mean & SD & Min-Maks & $95 \%$ CI \\
\hline Pretest & 8,57 & 2,373 & $4-13$ & $7,68-9,45$ \\
Post-Test & 12,33 & 1,605 & $10-15$ & $11,73-12,93$ \\
\hline
\end{tabular}

Based on table 2 above it is found that the average between knowledge before being given counseling for adolescents about PKPR with a mean value of 8.57 with a Standard Deviation of 2.373 knowledge of adolescents about PKPR after being given health education with a mean value of 12.33 with a standard of 1.605.

\section{Bivariate Analysis}

Table. 3

The Effect of Counseling on Adolescent Knowledge

\begin{tabular}{cccccc}
\hline Youth Knowledge & Mean & SD & SE & p-Value & N \\
\hline Pretest & $-3,767$ & 2,012 & $\begin{array}{l}0,433 \\
0,293\end{array}$ & 0,000 & \multirow{2}{*}{30} \\
Post-Test & & &
\end{tabular}

Based on table 3 the effect of counseling on adolescent knowledge shows that the mean value of the difference between knowledge before and after counseling with a mean value of 3.767, a standard deviation of 2.012. The statistical test results obtained a $\mathrm{p}$-value of 0.000 , so it can be concluded that there is a significant difference in value between the first knowledge and the second knowledge.

\section{DISCUSSION}

Before being given counseling, adolescent knowledge about PKPR was that the mean value was 8.57 with a standard deviation of 2.373. After being given counseling, adolescents' knowledge about PKPR obtained a mean value of 12.13 with a standard deviation of 2.013. It can be seen that the mean value of the difference between knowledge before and after counseling is -3.567 , with a standard deviation of 2.208. The results of statistical tests regarding adolescent knowledge about PKPR obtained a value of 0.005 ; it can be concluded that there is a significant difference between the first knowledge and the second knowledge of adolescents about PKPR at the Bintang Skilled Orphanage in Bengkulu City.

The importance of socialization about PKPR to adolescents significantly affects the knowledge of adolescents about PKPR. There is an increase in adolescent knowledge about PKPR after being given counseling. One of the changes in knowledge and attitudes can be influenced by health education in providing health counseling. Teenagers get learning and information from the counseling carried out to produce a change.

Previously, only $30 \%$ of adolescents knew the goals and services of the PKPR program. However, after being given counseling, the knowledge increased, namely that all of them answered the goals of PKPR correctly and knew the services that existed in the program, and teenagers knew the existence of PKPR services. Likewise, in adolescent knowledge about peer counselor duties and counseling goals that were part of the previous PKPR service, only $43 \%$ of adolescents did not answer correctly. After counseling, adolescent knowledge increased as much as $80 \%$ of adolescents answered 
the tasks and goals of counseling correctly.

Counseling that contains information related to PKPR to adolescents can influence adolescent knowledge. Adolescents must know that the existence of PKPR is a forum to overcome adolescent health problems. Health workers carry out health services in PKPR activities at health centers. PKPR services are in the form of health checks, counseling, and counseling aimed at increasing the knowledge and skills of adolescents in the prevention of health problems.

Research result Livana et al., (2018) shows that most respondents have better knowledge than before health education, the p-value $=0.001(<0.005)$. The results can be concluded that there is an increase in public knowledge before and after health education is carried out. Increased knowledge can be successful because of the learning process that occurs in a person. Knowledge is a fundamental domain in shaping one's actions. Research and behavioral experience based on knowledge will be more lasting than behavior that is not based on knowledge of the control group in future research. There is an increase in public attitudes before and after health education is carried out.

According to Ayu et al., (2020) the absence of PKPR socialization at the puskesmas significantly affects adolescents' efforts to implement health. Study Amieratunnisa \& Indarjo (2018) found that communication with youth as program targets only occurred through a few schools that supported the PKPR program. There are still many schools that do not support the PKPR program. Rahmah et al. (2020) stated that good knowledge in adolescents significantly affects adolescents in utilizing PKPR. The results show that adolescents' knowledge is as much as $41.9 \%$ have good knowledge that utilizes PKPR.

In line with research conducted by Yuniliza (2020) adolescents have high knowledge of PKPR services in the Padang Laweh Health Center Work Area, as evidenced by ten questions about adolescent knowledge related to PKPR, while half of the respondents do not know the PKPR program. Adolescents obtain knowledge in PKPR through counseling. Counseling aims to provide solutions to the problems that teenagers are facing.

There needs to be socialization with sectors related to program implementation so that there is feedback from related parties that support the success of the PKPR program (Pratiwi et al., 2018). Health promotion is carried out to direct adolescents by providing knowledge or information to determine the correct behavior choices to improve health or healthy behavior. The study results also conclude that the formation of behavior is influenced by adolescents' knowledge, attitudes, and actions (Akaputri et al., 2019).

\section{CONCLUSION}

There is an effect of counseling on adolescent knowledge about PKPR on average before and after counseling.

\section{SUGGESTIONS}

\section{Theoretical advice}

It is hoped that it can be used as a reference in conducting other health education in health services to increase the utilization of health services such as the Youth Care Health Service (PKPR). 


\section{Practice Advice}

\section{For Research Places}

There is counseling at the Bintang Terampil Orphanage for adolescent knowledge about PKPR so that teenagers can take advantage of PKPR services in the area.

\section{For Further Researchers}

It is expected to examine further how the influence of counseling on adolescent knowledge about PKPR and the use of PKPR programs, quantitative and more qualitative, to find out more in-depth knowledge of adolescents about PKPR.

\section{REFERENCES}

A’yun, L. Q., \& Qomaruddin, M. B. (2019). Evaluasi Pelaksanaan Program Pelayanan Kesehatan Peduli Remaja (PKPR) di Puskesmas Rangkah. Jurnal Keperawatan Muhammadiyah, 232-238. http://journal.um-surabaya.ac.id/index.php/JKM

Akaputri, D. E., Sutisna, M., Sugih, S., Wijayanegara, H., Sastramihardja, H., \& Rowawi, R. (2019). Pengaruh Penggunaan Teknik Digital Teenager Health Care Service (THE CARS) dalam Program Pelayanan Kesehatan Peduli Remaja (PKPR) terhadap Perubahan Perilaku Sehat Remaja Putri tentang Infeksi Menular Seksual (IMS) di SMA Negeri 1 Ciseeng Kabupaten Bogor. Jurnal Sistem Kesehatan, 5(2), 66-73. https://doi.org/10.24198/jsk.v5i2.25660

Amieratunnisa, A., \& Indarjo, S. (2018). Implementasi Program Pelayanan Kesehatan Peduli Remaja. Higeia Journal of Public Health Research and Development, 2(1), 69-79. http://journal.unnes.ac.id/sju/index.php/higeia

Ayu, M. D., Rifa'i, A., \& Liesmayani, E. E. (2020). Analisis Pemanfaatan Pelayanan Kesehatan Peduli Remaja (PKPR) di Wilayah Kerja Puskesmas Langsa Kota Tahun 2020. Journal of Healthcare Technology and Medicine, 6(2), 1127-1141. https://doi.org/10.33143/jhtm.v6i2.1159

Dewi, P. S. N., Shaluhiyah, Z., \& Suryawati, C. (2020). Analisis Implementasi Pelayanan Kesehatan Peduli Remaja (PKPR) di Puskesmas. Jurnal KESMAS (Kesehatan Masyarakat) Khatulistiwa, 7(3), 98-108. http://dx.doi.org/10.29406/jkmk.v7i3.2146

Febriawati, H., Padila, P., \& Anita, B. (2018). Pendidikan Seksual Remaja melalui POSKESJA. Jurnal Pengabdian Masyarakat Bumi Raflesia, 1(1), 45-53. https://doi.org/10.36085/jpmbr.v1i1.193

Kementerian Kesehatan Republik Indonesia. (2018). Data dan Informasi Profil Kesehatan Indonesia 2018. https://pusdatin.kemkes.go.id/resources/download/pusdatin/profil-kesehatanindonesia/Data-dan-Informasi_Profil-Kesehatan-Indonesia-2018.pdf

Kementerian Kesehatan Republik Indonesia. (2019). Profil Kesehatan Indonesia 2018. https://pusdatin.kemkes.go.id/resources/download/pusdatin/profil-kesehatanindonesia/PROFIL_KESEHATAN_2018_1.pdf

Livana, P., Yulianto, E., \& Hermanto, H. (2018). Pengaruh Pendidikan Kesehatan Personal Hygiene terhadap Tingkat Pengetahuan dan Sikap Masyarakat. Jurnal Keperawatan Komprehensif, 4(1), 1-6. https://doi.org/10.33755/jkk.v4i1.2

Pratiwi, T., Handayani, S., \& Isnaeni, Y. (2018). Analisis Implementasi Program Pelayanan Kesehatan Peduli Remaja (PKPR) di Puskesmas Kota Palembang. Jurnal Penelitian Kesehatan Suara Forikes, 9(3), 1-111. http://dx.doi.org/10.33846/sf.v9i3.230 
Rahmah, H., Amelia2, A. R., \& Hamzah, W. (2020). Faktor yang Berhubungan dengan Pemanfaatan Pelayanan Kesehatan Peduli Remaja di SMA Muhammadiyah 7 Makassar. Window of Public Health Journal, 1(2), 111-120. https://doi.org/10.33096/woph.v1i2.58

Riskesdas. (2018). Laporan Nasional Riskesdas 2018. Badan Penelitian dan Pengembangan Kesehatan. http://labdata.litbang.kemkes.go.id/images/download/laporan/RKD/2018/Laporan _Nasional_RKD2018_FINAL.pdf

Wijaya, V. F., \& Widjokongko, B. (2019). Pengaruh Penyuluhan Kesehatan Reproduksi terhadap Perubahan Tingkat Pengetahuan pada Wanita Usia Reproduksi di Desa Sabrang Delanggu Klaten. Jurnal IMJ: Indonesia Midwifery Journal, 2(2), 31-39. jurnal.umt.ac.id/index.php/imj/article/download/3065/1852

Yuniliza, Y. (2020). Faktor yang Berhubungan dengan Pemanfaatan Pelayanan Kesehatan Peduli Remaja (PKPR) di Puskesmas Padang Laweh. J-HESTECH (Journal of Health Educational Science and Technology), 3(2), 77-94. https://doi.org/10.25139/htc.v\%vi\%i.2863 